\title{
ANTISSEMITISMO E JURISDIÇÃO CONSTITUCIONAL: ANÁLISE DO CASO SIEGFRIED ELLWANGER
}

\author{
ANTI-SEMITISM AND CONSTITUTIONAL JURISDICTION: CASE SIEGFRIED ELLWANGER
}

Janaína Rigo Santin

Pós Doutorado em Direito Administrativo pela Universidade de Lisboa, Portugal, com bolsa CAPES, pelo período de 8 meses (2011). Doutorado em Direito pela Universidade Federal do Paraná (2004). Mestrado em Direito pela Universidade Federal de Santa Catarina (2000). Advogada e Professora Titular II da Universidade de Passo Fundo.

Faz parte do corpo docente permanente do Mestrado em Direito e do Mestrado e Doutorado em História da Universidade de Passo Fundo. Também atua na Universidade de Caxias do Sul, na faculdade de Direito. É professora colaboradora do Mestrado em Ciências Jurídicas-Econômicas e Desenvolvimento e do Mestrado em Governação e Gestão Pública da Universidade Agostinho Neto, em Luanda, Angola-África.

E-mail: janainars@upf.br

\section{Felipe Cittolin Abal}

Doutor em História pela Universidade de Passo Fundo (2016). Possui Mestrado em História pela mesma instituição (2012). Especialista em Direito do Trabalho Contemporâneo e Seguridade Social pela Universidade de Passo Fundo (2008). Possui graduação em Ciências Jurídicas e Sociais pela Universidade de Passo Fundo. Docente do Programa de Pós-Graduação em História da Universidade de Passo Fundo. É professor na Faculdade de Direito da Universidade de Passo Fundo desde 2009, ministrando as cadeiras de História do Direito, Direito do Trabalho e Processo do Trabalho.

E-mail: felipe.c.abal@hotmail.com

Recebido em: 11/02/2020

Aprovado em: 01/07/2020

RESUMO: Este artigo analisa, pela metodologia de estudo de caso, a decisão do Supremo Tribunal Federal quanto ao pedido de habeas corpus em nome de Siegfried Ellwanger no ano de 2003. O paciente era autor e editor de várias obras de cunho antissemita e, por este motivo, foi condenado pelo crime de racismo, imprescritível e inafiançável perante o ordenamento jurídico brasileiro, decisão atacada pelos impetrantes primeiramente junto ao Superior Tribunal de Justiça e, posteriormente, no Supremo Tribunal Federal. A importância da citada decisão se dá devido ao entendimento advindo acerca do crime de racismo e da possibilidade deste enquadramento em práticas de preconceito contra judeus. A decisão do caso concreto estudado pela jurisdição constitucional foi de negar o habeas corpus, mas não foi unânime, sendo possível verificar posicionamentos diversos tanto em relação à abrangência do crime de racismo quanto à interpretação do conteúdo dos livros escritos e publicados por Ellwanger. O antissemitismo é um fenômeno que perpassa séculos e a origem deste preconceito é amplamente debatida por diversos autores. O acórdão alvo do presente estudo revela a existência atual do preconceito contra as pessoas de origem hebraica e a necessidade de combate de qualquer tipo de discriminação por parte do Poder Judiciário.

Palavras-chave: Antissemitismo. Jurisdição constitucional. Liberdade de expressão. Racismo. 
Supremo Tribunal Federal.

ABSTRACT: This paper examines, by the case study methodology, the decision of the Federal Supreme Court regarding the request for habeas corpus on behalf of Siegfried Ellwanger in 2003. The patient was the author and publisher of several anti-Semitic works and, for this reason, was convicted of the crime of racism, imprescriptible and unenforceable before the Brazilian legal system, a decision attacked by the plaintiffs first at the Superior Court of Justice and, later, at the Federal Supreme Court. The importance of this decision is due to the understanding arising from the crime of racism and the possibility of this framing in practices of prejudice against Jews. The decision of the Federal Supreme Court was to deny habeas corpus, but it was not unanimous, and it was possible to verify different positions regarding both the scope of the crime of racism and the interpretation of the content of books written and published by Ellwanger. Anti-Semitism is a phenomenon that spans centuries and the origin of this prejudice is widely debated by several authors. The judgment of the present study reveals the current existence of prejudice against hebrew people and the need to combat any kind of discrimination by the judiciary.

Keywords: Anti-Semitism. Constitutional Jurisdiction. Freedom of expression. Racism. Brazilian Supreme Federal Court.

SUMÁRIO: Introdução; 1. O Antissemitismo; 2. Antissemitismo no Brasil e na América Latina; 3. As obras editadas por Siegfried Ellwanger; 4. Holocausto: judeu ou alemão - uma análise da obra de Ellwanger; 5. O Habeas Corpus 84.242-4/RS e seu julgamento pelo Supremo Tribunal Federal; Conclusão; Referências.

\section{INTRODUÇÃO}

Mesmo passados mais de dez anos do julgamento do Habeas Corpus 82.424-2 pelo Supremo Tribunal Federal, o qual tinha como paciente Siegfried Ellwanger, acusado por crime de racismo pela publicação de obras com caráter antissemita, sua análise tem extrema atualidade e importância. Em épocas de expansão em âmbito mundial de um pensamento de extrema direita, conservador, xenófobo, revisionista e intolerante com as diferenças, é preciso retomar este caso paradigmático à pauta das discussões, levando em conta tanto os argumentos jurídicos ali utilizados, ainda bastante atuais, quanto pela importância histórica do tema.

O caso, que teve certa repercussão à época do julgamento, trata-se de uma situação bastante rara no panorama jurídico brasileiro. Siegfried Ellwanger, que utilizava o pseudônimo de S. E. Castan, foi autor e editor de livros chamados "revisionistas", de cunho fortemente antissemita e que possuíam o intuito de questionar a existência do holocausto judeu durante a Segunda Guerra Mundial, defendendo a ideia de que diversos dos males da sociedade mundial eram oriundos da comunidade hebraica.

Devido à publicação destas obras, Siegfried Ellwanger foi condenado a dois anos de reclusão, calcado no crime de racismo previsto no artigo 20 da Lei 7.716/89, com redação dada pela Lei 8.081/90. Após uma tentativa frustrada de obter êxito em um habeas corpus junto ao Superior Tribunal de Justiça, buscaram os impetrantes desqualificar o crime de racismo junto ao Supremo Tribunal Federal, mediante novo habeas corpus, buscando desqualificar a sua conduta como crime de racismo. Caso este fosse aceito, o crime não seria mais tido como imprescritível e $\mathrm{o}$ ato não poderia mais ser punido. O estudo acerca das alegações dos impetrantes e do entendimento majoritário do STF em enquadrar o antissemitismo como uma forma de racismo é o foco central do presente artigo, com uma abordagem qualitativa, a partir da metodologia do estudo de caso. 
O antissemitismo é uma realidade bastante antiga na história mundial e diversos estudiosos, em especial das áreas da sociologia e da história, ocuparam-se em compreender as origens e os fundamentos deste fenômeno social, que perpassou centenas de anos e existe até hoje, mesmo após o triste episódio da Shoá (termo utilizado para designar o holocausto judeu), grandemente documentado e retratado em inúmeros livros, artigos, filmes e programas de televisão. Por este motivo, o primeiro passo a ser dado no presente estudo é uma breve abordagem acerca das origens do antissemitismo e suas aparições na história mundial e brasileira.

Posteriormente, passará a ser estudada aquela que é tida como a principal obra de Ellwanger, denominada "Holocausto: Judeu ou Alemão", para que, por fim, possa ser analisada a decisão do Tribunal e o entendimento dos ministros que participaram do julgamento.

O Brasil é conhecido comumente, e de forma bastante rasa, como um país sem preconceitos raciais, onde a miscigenação entre as diversas etnias que imigraram para o país teria terminado com a possibilidade de existência de racismo. Apesar disto, são bastante comuns casos noticiados a respeito de preconceito contra negros, indígenas e nordestinos. Pouco, porém, é divulgado a respeito do antissemitismo existente no país. Em uma rápida pesquisa na internet podem ser encontrados diversos sites que disseminam o ódio contra os judeus e fazem apologia ao nazismo, sendo que existe até mesmo um denominado "Partido Nacional-Socialista Brasileiro", com um plano de ação que envolve desde a divulgação de material nacional-socialista até a infiltração nos meios sociais para a difusão de seus ideais.

Esta é a principal motivação e importância deste estudo. O desconhecimento a respeito da existência do preconceito contra judeus ou o simples "olhar para o outro lado" diante desta situação é o primeiro passo para que absurdos maiores possam acontecer. Diante disto, a decisão do STF ora em análise se trata de um marco do judiciário brasileiro e merece grande destaque para que atos como os praticados por Siegfried Ellwanger sejam coibidos e nunca aceitos pela sociedade brasileira.

\section{O ANTISSEMITISMO}

O termo "antissemitismo" foi inventado e passou a ser amplamente utilizado a partir do século XIX, apesar de possuir uma falha etimológica por ser demasiadamente amplo. Nas palavras de Zygmunt Bauman (1988, p. 53-54) "representa o ressentimento contra os judeus. Refere-se à concepção dos judeus como um grupo estranho, hostil e indesejável e às práticas que derivam dessa concepção e a sustentam”.

Embora alguns autores sustentem que o antissemitismo surgiu com a destruição do segundo templo de Jerusalém no ano 70 d.C., (BAUMAN, 1998, p. 54) atos de agressão contra os judeus podem ser localizados muito anteriormente. Em 414 a.C., no Egito governado por Dario II, ocorreu o que pode ser tido como a primeira agressão religiosa direcionada aos judeus, com a destruição do santuário Judeu de Javé. (MESSADIÉ, 2003, p. 34)

Passado este fato, outras ações contra os judeus podem ser relacionadas na era pré-cristã, sendo quase unânime a posição de escritores e políticos gregos, romanos e egípcios de que os judeus tratavam-se de um povo à parte, destacado do restante da humanidade e que, sempre que possível, atacariam os demais povos. (MESSADIÉ, 2003, p. 34-48) Nos anos 38, 66, 70, 115 e 132 são documentados os primeiros pogroms da história, com o massacre de centenas de milhares de judeus, desencadeados pelos mais diversos motivos políticos e sociais. (MESSADIÉ, 2003, p. 7586)

Na era cristã, a situação dos judeus não sofreu qualquer melhoria, pelo contrário, foram considerados por um grande tempo como aqueles que traíram Jesus por dinheiro. A realidade teológica se perdeu com o passar dos anos em uma invenção que faz com que, até hoje, Judas, o judeu, seja sinônimo de ganância e traição perante muitos cristãos. (FINZI, 1999, p. 13) O batismo cristão tornou-se obrigatório para os judeus em Bizâncio (632), França (633) e Espanha (613).

Revista de Direito Brasileira | Florianólopis, SC | v. 25 | n. 10 | p. 162-182 | Jan./Abr. 2020 
Sinagogas foram destruídas ou confiscadas em Minorca em 418, Ravena em 495, Gênova em 500, entre outros locais, e os judeus destas cidades foram obrigados a se converterem ao cristianismo. (DE LANGE apud MESSADIÉ, 2003, p. 154)

A questão religiosa envolvendo ataques aos judeus não cessou no primeiro milênio da era cristã, sendo que, como bem aponta William Nichols, o Terceiro Reich não inventou nada mais em relação à perseguição dos judeus (com a exceção do holocausto) que a Igreja Católica já não tivesse feito. Do uso de uma insígnia nas roupas para identificar os judeus, prevista no Concílio de Latrão de 1215, até a proibição dos cristãos venderem bens aos judeus, decretada pelo sínodo de Ofen em 1279, (apud MESSADIÉ, 2003, p. 153) sendo que o autor, neste momento, se furta a versar sobre outra agressão importante: a perseguição dos judeus ocorrida durante a Inquisição.

Durante a Idade Média, o empréstimo de dinheiro era uma das poucas atividades permitidas para os judeus, uma vez que a denominada "usura" era proibida para os católicos desde o Segundo Concílio de Latrão de 1139. (FINZI, 1999, p. 15) O fato de serem experientes no empréstimo de valores e, muitas vezes, utilizados como administradores das finanças da nobreza fez com que os judeus, quando do crescimento da esfera econômica e política do Estado no século XVII, fossem procurados para auxiliar economicamente os Estados europeus que, por sua vez, passaram a dar aos judeus alguns privilégios e tratá-los como um grupo especial (ARENDT, 2006, p. 31).

Desta forma, durante os séculos XVII e XVIII, os judeus ricos e protegidos, denominados de "judeus-da-corte", podiam viver onde quisessem, viajar livremente pelo reino, portar armas, bem como possuíam proteção especial das autoridades locais. Isto ajudou ainda mais para a não assimilação dos judeus nos Estados em que viviam, o que ia ao encontro dos interesses da aristocracia da época, que necessitava de seus empréstimos, e dos judeus, que pretendiam sobreviver como um grupo. (ARENDT, 2006, p. 32-33)

Somente no final do século XIX, com o surgimento do imperialismo, que o fato de se realizar negócios com o Estado tornou-se atraente, o que caracterizou uma gradual perda pelos judeus de sua posição especial. A ligação dos judeus com a aristocracia, porém, permaneceu intocada para os gentios liberais, para quem ambas as figuras eram dois lados da mesma moeda. É notório que diversos judeus, destacados de sua comunidade, continuaram a financiar governos, como é o caso dos Rothschild na França, que prestaram serviços para Luís Felipe, para os Revolucionários e, depois, para Napoleão III. (ARENDT, 2006, p. 35-44)

Estes dois fatores, a ligação dos judeus com a aristocracia e seu apoio financeiro aos governos, desconectados de qualquer ideologia, gerou um crescimento do antissemitismo à época. Assim, junto das reações contra a aristocracia vieram os movimentos contra os judeus, sendo que muitos liberais pensavam que a melhor forma de se livrar da nobreza era, primeiramente, se desfazer dos judeus. No final do século XIX, quando a Europa sofreu com sérios escândalos financeiros e negócios fraudulentos que desencadearam uma enorme crise econômica, os judeus, patrocinadores dos regimes estatais e ligados ao sistema financeiro, foram acusados em larga escala de serem os geradores da ruína financeira das classes médias e inferiores. (ARENDT, 2006, p. 5256)

Para agravar ainda mais a situação do antissemitismo nos séculos XIX e XX, surgiram ainda diversas tentativas de explicações "racionais" para fundamentar o ódio contra os judeus. Em 8 de maio de 1920, o jornal americano The Times publicou um artigo onde revelava um suposto escrito que expunha uma associação diabólica, com fins de constituir a dominação mundial judaica através do ideário democrático socialista/comunista. Foi a primeira vez em que foi levado ao grande público a grande farsa chamada de "Os Protocolos dos Sábios do Sião". Este documento acabou por influenciar grandes parcelas da sociedade da época. Até mesmo o Ministro Winston Churchill e o Papa Bento XV chegaram a expressar temor em relação ao perigo de dominação judaico. (FINZI, 1999, p. 61-68) Até nos dias atuais, em círculos menos esclarecidos, "Os Protocolos dos Sábios do Sião" são citados como uma prova inequívoca de um complô judeu, 
sendo que, como se verá adiante, o livro chegou a ser publicado no Brasil, tendo como editor mais recente Siegfried Ellwanger.

Outras três obras merecem destaque com referência a um suposto "embasamento científico" para o antissemitismo: "Ensaio sobre a desigualdade das raças humanas" do francês Joseph Arthur de Gobineau; "Os Fundamentos do século XIX”, de Houston Stewart Chamberlain; e "O Mito do século XX" do nacional-socialista Alfred Rosenberg.

Gobineau provavelmente não era antissemita, porém, a sua obra citada trazia ideias de pureza racial, fundamento que seguiram os demais doutrinadores nazistas. $O$ francês, além da própria noção falsa de "raça", associou às diferentes raças características físicas e intelectuais. Os arianos possuiriam as virtudes da nobreza, da virtude, do amor pela liberdade e do culto da espiritualidade. Os judeus não foram mencionados no trabalho de Gobineau, porém, como eles não eram arianos, seriam, segundo os intérpretes racistas da obra, desprovidos de todas as virtudes arianas. (MESSADIÉ, 2003, p. 277)

Houston Chamberlain foi um inglês naturalizado alemão, genro de Richard Wagner e publicou "Os Fundamentos do século XIX" em 1899, livro que se tornou uma espécie de "bíblia do racismo", cuja obra se popularizou com extrema facilidade. Chamberlain utilizou das ideias de Gobineau, focando seu problema central na necessidade de preservação do sangue alemão, protegendo-o de ser adulterado por elementos exteriores. (FINZI, 1999, p. 93-94)

Rosenberg, por sua vez, era tido como o grande teórico do partido nazista e "O Mito do século XX" só estava atrás em importância de "Minha Luta". O tema fundamental da obra também era a raça e a pureza do sangue. Para o autor, a história humana caracterizava-se por uma tensão permanente entre os valores dos "nórdicos" (arianos) e os da "confusão racial"; portanto, o sangue ariano deveria ser salvo a qualquer custo. (FINZI, 1999, p. 91)

É possível notar, nesta sucinta explanação, diversos motivos que culminaram no maior horror do século XX: o holocausto. Os judeus, como um grupo à parte, às vezes tido como separado da sociedade e fechado em si mesmo, sofreram durante a história com acusações de cunho religioso, moral, político e pseudo-científico. Até hoje estes mesmos fundamentos são utilizados pelos antissemitas para buscar alguma razão para seu ódio. O holocausto será analisado mais profundamente a seguir, quando for tratada da obra de Ellwanger, em especial a denominada: "Holocausto: judeu ou alemão?". Porém, antes de terminada esta rápida incursão sobre o antissemitismo, cabe analisar sucintamente a respeito de como se deu este fenômeno no Brasil e na América Latina.

\section{ANTISSEMITISMO NO BRASIL E NA AMÉRICA LATINA}

Em 1492 o Rei e a Rainha da Espanha assinaram, com o apoio do Papa Sisto IV, o Decreto de Alhamba, expulsando do reino todos os judeus que não se convertessem ao cristianismo. Estimase que entre 200 e 400 mil judeus decidiram deixar o país e muitos fugiram para Portugal, de onde foram novamente expulsos em 1497. Por sua vez, no mesmo ano em que os judeus seriam mandados embora da Espanha, Cristóvão Colombo, que possivelmente seria judeu, chegava à América. Segundo o jornalista Baudouin Eschapasse:

Há quem diga que o próprio Cristóvão Colombo era um criptojudeu, mas não há provas que corroborem tal afirmação. A única certeza é que grande parte dos financiadores de sua expedição de 1492 era judia. Entre eles estavam Abraão e Isaac Abravanel, Juan Cabrero, Luis de Santángel, Gabriel Sánchez e Alfonso de la Caballeria. Segundo Lee Friedman, autor de um estudo sobre os pioneiros judeus do Novo Mundo intitulado Jewish pioneers and patriots (Pioneiros e patriotas judeus), vários membros da tripulação das três caravelas da expedição de Colombo seriam judeus. Alguns teriam, inclusive, criado raízes na América 
desde a primeira missão, em agosto-setembro de 1492. Cada nova onda de conquistadores trouxe novos criptojudeus. (ESCHAPASSE, 2009)

Diversos judeus, convertidos ao cristianismo apenas para escapar da fúria da Inquisição de Torquemada, conhecidos como marranos, chegavam ao Novo Mundo para reiniciar suas vidas. A maior parte dos territórios espanhóis estavam sob o olhar atento da Inquisição, que desconfiava profundamente dos marranos. O Brasil, cuja exploração foi confiada a um marrano, Fernando de Noronha, e teve como primeiro governador-geral Tomé de Souza, provavelmente também um marrano, escapou da presença da Muito Santa Inquisição até 1591. (MESSADIÉ, 2003, p. 284)

Assim, apesar da presença da Inquisição na América do Sul, alguns judeus conseguiram permanecer por algum tempo em terras brasileiras. Um recenseamento realizado no Brasil holandês revelava que este contava com 1.450 judeus em um total de 12.703 pessoas. (KATZ apud MESSADIÉ, 2003, p. 285) Foi exatamente no Brasil holandês, mais especificamente em Recife, que foi criada na década de 1630 a primeira sinagoga das Américas, denominada Kahal Zur Israel. Posteriormente, com a dominação desta parte do território brasileiro pelos portugueses, 23 judeus fugiram do país rumo à América do Norte, onde iniciaram a colonização daquela que viria a ser a cidade de Nova Iorque. (SILVA, 2010)

Segundo Maria Luiza Tucci Carneiro (1988, p. 195): “O preconceito racial foi uma realidade no Brasil, durante os três séculos em que foi colônia de Portugal. Judeus, mouros, negros, mulatos, indígenas, cristãos-novos e ciganos eram considerados inaptos para participar da sociedade colonial". Este preconceito contra os judeus e cristãos-novos era mais religioso e legal do que prático, uma vez que não se chegaram a verificar agressões contra pessoas de origem hebraica, apesar de existir a perseguição dos judeus por parte do Tribunal da Inquisição no Brasil. A partir do século XVII, os cristãos-novos começaram a chegar ao país em maior quantidade, buscando melhores condições de vida, crescimento econômico e um refúgio da inquisição, exercendo diversas atividades, desde a ocupação de importantes funções públicas a simples lavradores e homens de negócios. (CARNEIRO, 1988, p. 196-199)

Em 1624 a preocupação com os judeus aumentou: a Coroa portuguesa proibiu licença aos homens de negócio de origem hebraica para venderem suas fazendas, e o próprio ex-governador do Brasil, D. Luis de Souza, foi acusado de promover cristãos-novos a cargos públicos importantes. A tensão existente contra aqueles de descendência hebraica permaneceu e a tentativa de isolamento sempre foi um escape para as perseguições sofridas. (CARNEIRO, 1988, p. 201-203)

Importante ressaltar uma alteração ocorrida em 1773, com a edição em Portugal de uma lei promulgada pelo Marquês de Pombal que proibia a distinção entre cristão-novo e cristão-velho, em uma tentativa de reduzir os abusos existentes contra os primeiros. Com a edição desta CartaLei, a diferenciação entre os judeus convertidos e os cristãos deixou de existir legalmente, fazendo com que a discriminação fosse reduzindo gradualmente, apesar de ainda existir o preconceito. (CARNEIRO, 1988, p. 221)

Por sua vez, com a independência do Brasil, surgiu a necessidade de uma Constituição que trouxesse mais legitimidade ao país. A Constituição Imperial de 1824, outorgada por D. Pedro I, trazia em seu artigo 5: "A Religião Catholica Apostolica Romana continuará a ser a Religião do Imperio. Todas as outras Religiões serão permitidas com seu culto domestico, ou particular em casas para isso destinadas, sem fórma alguma exterior do Templo." Desta forma, apesar de uma aparente liberdade religiosa, a Constituição de 1824 fazia com que os judeus não pudessem professar sua religião em uma sinagoga propriamente dita, mas apenas dentro de locais particulares e sem aparência de um templo. (WOLFF; WOLFF, 1975, p. 6-7)

Porém, essa mudança de política frente aos judeus, liberando-os para professar a religião, mesmo que privadamente, não tardou a trazer resultados e, no século XIX, muitos judeus franceses e ingleses imigraram para o Brasil, fazendo com que fossem um povo cada vez mais presente no 
país. O próprio Dom Pedro II possuía um conhecido interesse pelo hebraico. Nas palavras de Keila Grinberg (2019, p. 2-3):

[...] consta que ele havia estudado um pouco a língua com um judeu sueco que morava em Petrópolis por volta de 1860, para entender melhor a história dos hebreus e a origem do cristianismo. Pedro II chegou, inclusive, a viajar para a região hoje compreendida por Israel, à época parte do Império Otomano, para conhecer a chamada Terra Santa, em uma das grandes viagens empreendidas por ele na década de 1870, quando também foi ao Egito.

Apesar da falta de condições para que fosse possível uma verdadeira liberdade de culto, a vida dos judeus durante o império transcorreu normalmente, e um grande número de judeus acabou por se instalar por todo o país, em especial na Amazônia. (GRINBERG, 2019, p. 4)

Já durante a república, o status Constitucional da liberdade religiosa dos judeus foi melhorado, dispondo o artigo 11 da Constituição de 1891: “Art 11 - É vedado aos Estados, como à União: (...) $2^{\circ}$ - estabelecer, subvencionar ou embaraçar o exercício de cultos religiosos." Desta maneira, a liberdade para estabelecer sinagogas em território brasileiro estava garantida, facilitando o acesso dos judeus a instalações que permitissem a materialização e exteriorização de sua crença religiosa.

Com a revolução de 1930 o clima político do país mudou bruscamente. A perseguição aos comunistas e à esquerda em geral, comungada com a identificação dos judeus com o comunismo criada pelos integralistas, gerou uma redução drástica da imigração de judeus para o Brasil, sendo que os cônsules brasileiros na Europa receberam ordens diretas para negarem vistos a toda pessoa que tivesse origem semita. (BEN-DROR, 2007, p. 209) Essa situação foi alterada na década de 1940, quando um fato fez a imagem do Brasil frente aos judeus mudar: a participação de Oswaldo Aranha na criação do Estado de Israel. Aranha era, em 1947, presidente da Assembleia Geral das Nações Unidas e encarregado da partição da Palestina. Juntamente com o representante brasileiro nas Nações Unidas, João Carlos Muniz, apoiou ferrenhamente a resolução e, dois meses após a sua posse, o Estado de Israel se tornou uma realidade. (LESSER, 2007, p. 274)

Portanto, pode-se constatar que, durante as décadas de 1930 e 1940, o Brasil sofria de um racismo direcionado ao "judeu imaginário", o que levava a que o "judeu real", presente na sociedade brasileira, pouco sofresse com preconceitos oficiais por parte do Estado. Segundo Lesser (2007, p. 276), "para imigrantes e refugiados judeus, o simples ato de entrar no Brasil, seja por meios legais ou ilegais, normalmente os transformava de indesejáveis em elementos bem-vindos".

Por sua vez, a questão do antissemitismo durante o governo militar até a democratização do país é pouco explorada. Porém, pode se denotar que na história brasileira em geral, o antissemitismo somente em raros casos tomou um corpo institucionalizado no governo, uma vez que, no dia-a-dia, em comparação com o racismo existente em outros locais, como na Argentina e na Europa, os judeus conseguiram levar uma vida normal. O caso ora em análise, referente a Siegfried Ellwanger, porém, é uma prova de que, apesar de o Brasil se considerar uma nação plural e multiétnica, sempre existem elementos que destoam desta linha e demonstram que o preconceito e, em sua faceta mais nefasta, o racismo, tem a lamentável característica de nunca desaparecer.

\section{AS OBRAS EDITADAS POR SIEGFRIED ELLWANGER}

Neste momento cabe colocar quais as obras escritas e editadas por Siegfried Ellwanger ensejaram o processo penal contra ele e sua respectiva condenação, que foi atacada via habeas corpus impetrado no Supremo Tribunal Federal brasileiro. Antes de ingressar no tema especificamente, cabe expor uma breve biografia de Ellwanger, que, apesar da fonte duvidosa, advinda de um de seus maiores admiradores, Alfredo Braga, é de certa utilidade. 
Ellwanger, gaúcho descendente de alemães, nascido em Candelária no ano de 1928, realizou os estudos primários nesta cidade e, posteriormente, em Santa Cruz do Sul. Após trabalhar como operário em algumas fábricas da região, alistou-se no Exército, onde ficou por três anos. Em 1948 iniciou a laborar no ramo de ferro e aço, e, na década de 1950, fundou sua própria empresa no mesmo ramo, tendo obtido algum sucesso. Com a venda de sua empresa vinte anos depois, Ellwanger pôde passar a se dedicar a seus estudos "históricos", de onde derivaram seus livros, sempre assinados sob o pseudônimo de S. E. Castan, tendo fundado, posteriormente, a "Editora Revisão". Apesar da sua defesa ferrenha ao regime ditatorial e criminoso de Adolf Hitler, Ellwanger se diz socialista (o que é uma grande contradição com seus escritos), tendo sido membro do Partido Socialista Brasileiro e do Partido Democrático Trabalhista e afirmado, antes de sua morte, em setembro de 2010, ser um simpatizante do Partido dos Trabalhadores. (BRAGA, 2019)

Como se pode denotar, Ellwanger era uma pessoa de pouca instrução, que teve alguma perspicácia para a atividade empresarial. Aposentado, dedicou seu tempo livre a revelar o que ele denominava de "a mentira do século", procurando, mediante argumentos rasos, negar a existência do holocausto, bem como vitimizar a Alemanha durante a Segunda Guerra e expor um complô judaico de dominação mundial.

Ellwanger foi o autor dos seguintes livros: "Nos bastidores da mentira do século"; "Acabou o gás... O fim de um mito"; "SOS Alemanha"; "A implosão da mentira do século"; "A verdade sobre o 'diálogo' católico-judaico no Brasil"; e "Holocausto judeu ou alemão: nos bastidores da mentira do século". Além das obras autorais, através da Editora Revisão, Ellwanger editou e publicou os livros "O judeu internacional", de Henry Ford; "A história secreta do Brasil", "Brasil colônia de banqueiros" e "Os protocolos dos sábios de Sião", os três de autoria de Gustavo Barroso; "Hitler: culpado ou inocente", de Sérgio Oliveira; e "Os conquistadores do mundo - os verdadeiros criminosos de guerra", de Louis Marschalko. Antes de versar especificamente a respeito das obras escritas por Ellwanger, cabe expor brevemente a respeito das principais obras por ele editadas.

Henry Ford, o famoso industrialista americano, era tomado por um forte antissemitismo, o que o levou a publicar em 1920 o livro "O Judeu Internacional", uma obra bastante extensa e repleta de acusações contra os judeus e impressões do magnata estadunidense a seu respeito. $\mathrm{O}$ livro, na realidade, pouco difere dos demais textos antissemitas. Ford coloca que o sistema financeiro mundial se encontrava, estranhamente, nas mãos dos judeus, mesmo eles representando uma parcela ínfima da sociedade, o que traduziria, sem sombra de dúvida, a intenção dos judeus dominarem o mundo. (FORD, 1989, p. 11-20) Ainda, pode-se denotar claramente em sua obra a influência dos Protocolos dos Sábios do Sião, que há pouco haviam sido publicados, uma vez que Ford encara a Primeira Guerra Mundial como um claro exemplo da aplicação prática desse documento. (FORD, 1989, p. 108) Ford não deixava a suposta influência judaica restrita ao panorama econômico, colocando que também a indústria cinematográfica (FORD, 1989, p. 198202) e o teatro americanos seriam instrumentos pró-sionismo. (FORD, 1989, p. 191-197) Sequer o jazz, ritmo tido tipicamente como negro, escapou da paranoia do industrialista. Para o autor, o jazz seria uma tática usada pelos judeus, donos das gravadoras, para introduzir o ritmo "selvagem" nos lares das famílias mais decentes:

O que tem de insípido, de viscoso, de contrafeito, o sensualismo animal: tudo é de origem judaica. Guinchos de monos, grunhidos da selva virgem, vozes de besta enciumada, combinam-se com algumas notas semimusicais e dessa forma o espírito genuinamente judeu penetra nas famílias que em outros tempos teriam repelido indignadas costumes tão extravagantes. (FORD, 1989, p. 258)

Na última parte da obra, Ford passa expor a forma como os judeus estariam tentando implementar o bolchevismo nos Estados Unidos, o que seria mais uma forma de desestabilização e tentativa de domínio. (FORD, 1989, p. 264) Na realidade, pode-se aqui destacar a incrível

Revista de Direito Brasileira | Florianólopis, SC | v. 25 | n. 10 | p. 162-182 | Jan./Abr. 2020 
habilidade deste grupo de antissemitas em fazer com que os judeus, de um lado, pareçam ser o ápice do capitalismo, controlando as finanças mundiais, monopolizando o ramo dos empréstimos e sendo a figura por trás das grandes indústrias; e, de outro, sejam os grandes fomentadores do comunismo mundial. Este paradoxo parece estar presente, por vezes, ainda hoje em alguns discursos mais desavisados. A obra de Ford, criticamente, parece mais um compêndio de "lamentações" do magnata do que uma tentativa de exposição de fatos que beirem qualquer cientificismo. $O$ industrialista, ainda, deixa no ar uma grande questão: como, em um mundo dominado por judeus, um "puro sangue" como Ford havia conseguido chegar a uma posição de destaque?

Gustavo Barroso, por sua vez, é um "velho conhecido" dos brasileiros. Barroso foi um dos líderes da Ação Integralista Brasileira e era um notório antissemita. Suas ideias se aproximavam mais do nazismo do que do fascismo, o que o diferenciava de Plínio Salgado. (CPDOC, 2019) Autor de uma extensa lista de obras (muitas delas abertamente racistas), Barroso foi membro da Academia Brasileira de Letras, ocupando a cadeira 19 em 1923. (CPDOC, 2019).

Em "História secreta do Brasil", uma obra dividida em seis volumes, Gustavo Barroso pretendeu realizar uma releitura da história brasileira, colocando já no seu primeiro volume, quando trata do descobrimento do Brasil, a presença de judeus ávidos por angariar lucro a qualquer custo, iniciando pela exploração do pau-brasil, (BARROSO, 1990, p. 29-33) passando para a cana de açúcar, (BARROSO, 1990, p. 37-53) até a venda de escravos. (BARROSO, 1990, p. 54-64)

Barroso afirma, até mesmo, que a conhecida "Revolta dos Mascates" fora, na realidade, uma "guerra judaica" com a finalidade de usurpar toda a riqueza do país para os judeus. (1990, p. 116-129) E finaliza o primeiro volume de sua obra afirmando que a maçonaria também tivera forte presença na história brasileira, tida como uma apoiadora e "abre alas" para as intenções do judaísmo. (1990, p. 145-180) Para não delongar-se demasiadamente nesta obra de Barroso, cabe explanar que os demais volumes que a compõe repetem a mesma ideia, inserindo em diversos capítulos da história do Brasil a influência judaico-maçônica com o fim único de se obter lucros às custas da terra brasileira e dos brasileiros, indo ao encontro do ideário integralista de que era necessário proteger a "brasilidade" destas malévolas influências estrangeiras e antinacionais.

Em relação a Barroso, deve-se falar ainda a respeito da que talvez tenha sido sua obra de maior impacto em relação ao antissemitismo: a sua tradução dos "Protocolos dos sábios de Sião", publicada originalmente em 1930, sete anos após seu ingresso na Academia Brasileira de Letras. Infelizmente esse texto, assim como ocorrera no exterior, influenciou muitos políticos e intelectuais brasileiros, da mesma forma que "O judeu internacional", de Henry Ford, tratado anteriormente. (BEN-DROR, 2007, p. 226-227)

O livro de Sérgio Oliveira carece de maior análise em virtude das conclusões que podem ser tiradas a partir do seu título. Em "Hitler: Culpado ou inocente?", Oliveira, um militar do exército brasileiro, coloca toda a culpa pelo início da Segunda Guerra Mundial nos judeus. Além disso, afirma não ter ocorrido o holocausto, iniciando sua obra como se estivesse tratando de uma nova cruzada cristã contra os infiéis:

Enquanto os cristãos pautam o seu modus vivendi nas mensagens de amor, harmonia, igualdade e irmandade entre os povos, contidas no Novo Testamento, os judeus seguem o Torah, cujo teor aponta para o ódio a tudo o que não for judeu, para a desarmonia, para a desigualdade e para o desentendimento entre os povos (porque é dividindo que mais facilmente se conquista). (OLIVEIRA, 1990, p. 15)

Este livro, analisado de forma crítica, não passa de uma "colagem" de textos que visam desfazer os relatos existentes a respeito das atrocidades nazistas durante a Segunda Guerra Mundial. O militar pretendeu, até mesmo, equiparar as condições de vida em um campo de concentração àquelas vividas por qualquer soldado em uma caserna, bem como justificar as mortes ali ocorridas: 
Claro que muitos morreram nos campos de concentração alemães: morreram porque se portaram como os passageiros dos vagões onde imperou a lei do "salvese quem puder"; morreram outros porque não estavam acostumados ao desconforto; e ainda outros porque foram atacados pelas epidemias (resultantes da falta de higiene); e, finalmente, outros morreram em tentativas de fuga, ou fuzilados por infringir o regulamento. Houve os que foram vítimas de excessos e isto seria uma exceção se não tivesse ocorrido. Como já se teve oportunidade de ressaltar, sádicos existem em todas as sociedades. Há que levar em consideração o fato de que os alemães estavam acossados por todos os lados. A nação enfrentava um punhado de inimigos. Suas cidades eram diariamente bombardeadas. Centenas de milhares de civis inocentes, mesmo em cidades abertas - como Dresden, morriam a cada dia. O que se poderia esperar de um soldado que tivesse perdido os familiares mais caros em um desses bombardeios? Era possível exigir que tratassem os inimigos com benevolência? Excessos foram registrados. Mas foram casos esparsos, muitas vezes punidos exemplarmente. (OLIVEIRA, 1990, p. 82)

Por fim, a seguir, se fará uma análise daquela que talvez tenha sido a principal obra escrita pelo próprio Ellwanger: "Holocausto: Judeu ou alemão?", para que se possa ter uma noção a respeito do perverso conteúdo dos livros escritos pelo ator em análise neste estudo.

\section{HOLOCAUSTO: JUDEU OU ALEMÃO - UMA ANÁLISE DA OBRA DE ELLWANGER}

A obra "Holocausto: judeu ou alemão", escrito por Siegfried Ellwanger, trata-se de uma mixórdia de impressões pessoais a respeito de fatos que vão desde as Olimpíadas de Berlim, de 1936, até o pós-Segunda Guerra Mundial. Apesar de o autor afirmar que o livro é resultado de "uma pesquisa histórica", (CASTAN, 1987, p. 9) nenhuma de suas afirmações são focadas em documentos originais ou fontes primárias, partindo suas conclusões de textos retirados de livros escolhidos "a dedo" para respaldar suas opiniões, como a que afirma haver uma "suposta falta de provas" quanto ao holocausto judeu ocorrido durante o período da Alemanha nazista. O objetivo do livro fica claro no seu prefácio, de autoria própria, onde diz que quer rever a história referente ao holocausto, bem como a defesa da revogação das leis que tratam os crimes contra a humanidade como imprescritíveis. Ao fim do prefácio, de uma forma que beira o cinismo, Ellwanger (ou Castan, como assinava) afirmou que: "Qualquer citação sobre o Sionismo ou referências sobre Judeus Internacionais não deverá ser considerada contra pessoas que professam a religião judaica, que residem e trabalham pacificamente conosco". (CASTAN, 1987, p. 10)

Em sua primeira parte, o livro pretende corrigir as informações em relação às Olimpíadas de Berlim de 1936, afirmando que não houve preconceito contra os atletas negros (em especial Jesse Owens) e que a Alemanha não havia sido derrotada nos jogos olímpicos. A popularidade de Owens na Alemanha, inclusive, foi tida pelo autor como prova irrefutável da inexistência de racismo no país. Sobre o assunto, assim dispõe o autor: 'O 'negrão' era tão querido e popular no povo alemão que não teve, após a primeira vitória, praticamente mais descanso, pois onde andava tinha que dar autógrafos". (CASTAN, 1987, p. 13) Ellwanger termina esta parte do livro expondo o quadro de medalhas das referidas Olimpíadas, demonstrando a partir disso que não haveria motivos para o Führer odiar os afro-americanos, uma vez que a Alemanha ganhara um número igual de medalhas aos Estados Unidos, França e Grã-Bretanha somados. (CASTAN, 1987, p. 1516)

Na sequência, o autor utiliza várias obras e textos para fundamentar o conflito existente entre arianos e judeus. Chama a atenção Ellwanger alegar que uma de suas "fontes" seria um judeu berlinense com quem ele havia conversado em um café na Alemanha, o qual teria afirmado "Somos 
uma raça marcada. Vivemos sob perseguições porque, infelizmente, nos falta o senso de autocrítica". Para o autor, esta afirmação é prova irrefutável de que os judeus (pelo menos em grande parte) foram os culpados pelo que lhes ocorreu durante o regime nazista. (CASTAN, 1987, p. 19)

O livro de Henry Ford, citado anteriormente, também é ressaltado por Ellwanger, sendo que o autor copia trechos de "O judeu internacional" por cinco páginas, com pequenos comentários. (CASTAN, 1987, p. 21-26) Posteriormente, passa a versar sobre os antecedentes da Segunda Guerra, iniciando pela derrota da Alemanha na Primeira Guerra, decorrente, segundo Ellwanger, de uma greve geral ocorrida por influência dos bolcheviques e redundando no Tratado de Versalhes, para o autor totalmente injusto e humilhante. (CASTAN, 1987, p. 29-35)

Assim como em outras obras antissemitas, Ellwanger faz a ligação entre comunismo e judaísmo, alegando que os principais postos da União Soviética eram geridos por judeus e, até mesmo Lênin, que não era de descendência judaica, sofria de uma grande "queda" pelo sionismo, tendo inclusive casado com uma hebreia. (CASTAN, 1987, p. 38-40) Segundo o autor, já em 1934 jornais judaicos prometiam que a Alemanha, no próximo conflito, seria destruída. Com esta afirmativa, a intenção do autor era revelar que era por parte dos "inimigos do Reich" que surgiria a iminente guerra. (CASTAN, 1987, p. 43) Para ele, como consequência desta propaganda judaica e da influência bolchevique, a Polônia teria iniciado as agressões contra a Alemanha, "obrigando" Hitler a declarar guerra, apesar de ele, conforme suas conclusões, sempre permanecer voltado à paz. Afirma Ellwanger, na sequência, que os ingleses aderiram à guerra por pressão dos judeus americanos, levando a França consigo. (CASTAN, 1987, p. 63-76)

A Alemanha, então, obrigada a invadir a Polônia para conter o avanço russo, no seu entender permitiu que os judeus vivessem tranquilamente. Para embasar esta afirmação o autor utiliza a obra "Um repórter brasileiro na Guerra Européia", de Alexandre Konder, até hoje muito utilizada por revisionistas. Konder, citado por Ellwanger, dispõe então: "No Protetorado, onde é grande a população judaica, esta não usa braçadeiras, nem sofreu, tão pouco, a menor restrição nas suas atividades normais. As casas de comércio israelitas funcionam como as demais". (CASTAN, 1987, p. 94) Até este momento, o autor se fixa, portanto, em afirmar os desejos de Hitler pela paz, tendo sido obrigado a entrar em um conflito devido ao "complô judaico internacional", apesar dos nazistas, nos territórios ocupados, tratarem os judeus com todo o respeito possível.

No caso da ocupação alemã na França, segundo o autor, o panorama era similar, tanto que Sir Alan Brooke (general inglês) teria afirmado que "A população francesa não pareceu, de modo algum, satisfeita com a nossa chegada como exércitos vitoriosos para libertar a França. Estavam inteiramente felizes como eram e nós trazíamos a guerra e a desolação ao seu país". (CASTAN, 1987, p. 118)

Hitler teria, ainda, resistido a todas as provocações americanas para impedir o ingresso dos Estados Unidos na guerra, já que seu interesse maior era a paz mundial. Diante disto, Roosevelt e Churchill criaram um engodo para forçar a entrada dos Estados Unidos na Guerra, colocando uma frota inerte em Pearl Harbor como uma "isca" que os japoneses não deixaram de abocanhar, resultando no ingresso americano na guerra. (CASTAN, 1987, p. 133-134) Chega-se, então, ao ponto mais nefasto da obra do gaúcho, quando passa a versar sobre o holocausto, denominado por ele de "a mentira do século". Para Ellwanger (codinome Castan)

Com estudos feitos por cidadãos de países que lutaram contra a Alemanha, tanto o número de 6 milhões de judeus mortos, como as respectivas histórias de câmaras de gás, não passam de uma grosseira mentira, cuja maior vítima é justamente a Alemanha, que já pagou indenizações beirando a casa dos cem bilhões de marcos [...] Considerando que o sionismo já dominava a imprensa mundial, imaginem só como este domínio foi ampliado após a Segunda Guerra Mundial até os nossos dias. (CASTAN, 1987, p. 136) 
O autor passa a afirmar, então, sobre a inexistência das câmaras de gás, colocando que o grande número de mortos encontrados nos campos de concentração se deveu às doenças existentes e, principalmente, aos bombardeios aliados ocorridos nos campos, já que para ele nunca teria havido uma ordem de extermínio de judeus por parte do Führer. (CASTAN, 1987, p. 137-145) Os campos de concentração, segundo o autor, não passavam de "prisões de luxo", uma vez que, em suas palavras:

o lema de todos os campos era "Arbeit Macht Frei” - O trabalho liberta - Devo citar que os pavilhões do campo de concentração de Auschwitz, onde estive em 1985 durante dois dias, são, transcorridos mais de 40 anos de sua construção, mais resistentes, melhor construídos e em melhor estados (sic) que os pavilhões do Corpo de Fuzileiros Navais, da ilha das Cobras, no Rio de Janeiro, onde servi de 1946/48. Não quero dizer com isto que os pavilhões dos fuzileiros fossem maus; quero apenas dizer que os pavilhões de Auschwitz são excelentes! (CASTAN, 1987, p. 148)

Em seguida, Ellwanger passa a explanar a respeito da impossibilidade de existência das câmaras de gás, crematórios e qualquer outro método de assassinato em massa, utilizando de excertos de depoimentos e concluindo "racionalmente" por ser inacreditável a versão do holocausto publicado pela imprensa judaica. (CASTAN, 1987, p. 152-196) Talvez a parte mais absurda da obra de Ellwanger seja a em que ele passa a analisar fotos de campos de concentração, alegando que estas não passam de falsificações, desenhos e adulterações, já que não existiriam presos esqueléticos nos campos ou qualquer outro tipo de maus-tratos, muito menos assassinatos em massa. Ao invés das mulheres nuas e magérrimas que apareciam nas fotos, a realidade, segundo o germanófilo, eram judias gordinhas se insinuando para o fotógrafo. (CASTAN, 1987, p. 221-247)

Ao final desta breve análise desta obra de Ellwanger, que contém muitos outros absurdos passíveis de destaque, cabe transcrever um parágrafo muito curioso de seu epílogo. Apesar de sua nítida aversão aos judeus e simpatia desenfreada pelo nazismo, o autor coloca que:

este livro nada tem a ver com os brasileiros natos ou naturalizados que professam a religião judaica [...] O que não é aceitável é uma dupla nacionalidade. Uma boa forma de combater o sionismo: Nunca discriminar o brasileiro nato ou naturalizado que professa a religião judaica! (CASTAN, 1987, p. 305)

Passado este estudo a respeito de Ellwanger, contendo uma rápida análise acerca das obras editadas e escritas por ele, pode-se chegar à conclusão de que ele nitidamente expressava um preconceito contra os judeus. Gastar mais de trezentas páginas para inocentar o nazismo e culpar os judeus dos grandes males do mundo para, ao final, inserir um pequeno parágrafo dizendo não estar se referindo aos judeus brasileiros, não exime a grande carga de racismo existente em seu trabalho. Qualquer leitor levemente propenso ao antissemitismo que tivesse acesso a estas obras teria uma grande propensão a voltar-se contra todos os judeus.

\section{O HABEAS CORPUS 84.242-4/RS E SEU JULGAMENTO PELO SUPREMO TRIBUNAL FEDERAL}

Siegfried Ellwanger foi condenado, em julgamento ocorrido em 31 de outubro de 1996, à pena de dois anos de reclusão com sursis (suspensão condicional da pena), pelo delito de discriminação contra os judeus - racismo. Essa pena se deu quatro anos, onze meses e dezessete dias após o recebimento da denúncia. (BRASIL, 2003, p. 203-204) Ocorre que, conforme os artigos 
109 e 110 do Código Penal Brasileiro ${ }^{1}$, caso se tratasse de um crime comum, não haveria possibilidade de ser aplicada a pena contra o réu, uma vez que o crime estaria prescrito, ante a passagem de mais de quatro anos da denúncia realizada pelo Ministério Público. Porém, o entendimento da jurisdição constitucional deu-se no seguinte sentido: por se tratar de crime de racismo previsto na Constituição Federal em seu artigo 5, XLII, não há prescrição:

Art. $5^{\circ}$ Todos são iguais perante a lei, sem distinção de qualquer natureza, garantindo-se aos brasileiros e aos estrangeiros residentes no País a inviolabilidade do direito à vida, à liberdade, à igualdade, à segurança e à propriedade, nos termos seguintes: [...] XLII - a prática do racismo constitui crime inafiançável e imprescritível, sujeito à pena de reclusão, nos termos da lei;

Foi exatamente contra o enquadramento dos atos antissemitas praticados por Ellwanger como crime de racismo que se voltaram o advogado Werner Becker e a estagiária Rejana Becker. Isso porque acaso o crime cometido pelo réu fosse desqualificado da tipificação de racismo, teria ocorrido a prescrição, eis que um crime comum. Assim, na tentativa de obter esta desqualificação foi que os advogados ingressaram em nome do paciente Siegfried Ellwanger com o remédio do habeas corpus. Primeiramente foi interposto no Superior Tribunal de Justiça e, como foi negado provimento neste tribunal, interpuseram novo habeas corpus no Supremo Tribunal Federal, com pedido liminar de que fosse retirada a característica de imprescritibilidade do crime cometido.

A tese principal aventada pelos impetrantes do habeas corpus foi de que, baseado em diversos autores de origem judaica, os judeus não seriam uma "raça", sendo, portanto, impossível o crime de racismo contra eles, bem como a sua imprescritibilidade. Seria, portanto, o crime cometido por Ellwanger tido como comum e, portanto, prescritível. (BRASIL, 2003, p. 203-204)

Após o indeferimento da liminar requerida, pronunciou-se o Procurador Geral da República, Cláudio Lemos Fonteles, que deu parecer no sentido de indeferir o habeas corpus, uma vez que o crime de racismo previsto na Constituição Federal era regulamentado pela Lei 7.716/89, posteriormente alterada pela Lei 8.081/90, tendo o seu artigo 20 seguinte redação:

Art. 20. Praticar, induzir ou incitar, pelos meios de comunicação social ou por publicação de qualquer natureza, a discriminação ou preconceito de raça, por religião, etnia ou procedência nacional. Pena: reclusão de dois a cinco anos.

Assim, no entendimento do Procurador Geral, interpretando-se o racismo previsto na Constituição sob a ótica da Lei que versava especificamente sobre este crime, era claro que não somente a questão da "raça" devia ser levada em conta, mas também qualquer tipo de discriminação baseada em cor, etnia, religião e procedência nacional. Portanto, o paciente do habeas corpus Siegfried Ellwanger havia cometido, na ótica de Fonteles, um crime imprescritível. (BRASIL, 2003, p. 204-206)

Em 24 de março de 2003 foi juntado aos autos um parecer quanto ao caso, formulado por Celso Lafer, ex-Ministro das Relações Exteriores brasileiro. O jurista rebateu com veemência os argumentos expostos pelo impetrante no habeas corpus, entendendo que limitar o crime de racismo ao conceito biológico de raça seria esvaziar completamente os objetivos da Constituição Federal de 1988, que trazia em seu corpo expressamente a previsão de tal delito. Cita o parecerista o embaixador Lindgren Alves: "a inexistência de raças poderia representar a inexistência do racismo, justificando uma inação, que ninguém ousaria, na Conferência, suscitar como posição" (LAFER,

\footnotetext{
${ }^{1}$ Art. 109 - A prescrição, antes de transitar em julgado a sentença final, salvo o disposto nos $\S \S 1^{\circ}$ e $2^{\circ}$ do art. 110 deste Código, regula-se pelo máximo da pena privativa de liberdade cominada ao crime, verificando-se:

$\mathrm{V}$ - em quatro anos, se o máximo da pena é igual a um ano ou, sendo superior, não excede a dois;

Art. 110 - A prescrição depois de transitar em julgado a sentença condenatória regula-se pela pena aplicada e verificase nos prazos fixados no artigo anterior, os quais se aumentam de um terço, se o condenado é reincidente
}

Revista de Direito Brasileira | Florianólopis, SC | v. 25 | n. 10 | p. 162-182 | Jan./Abr. 2020 
2005, p. 49). O entendimento central do jurista foi no sentido de que o racismo, portanto, não poderia ser compreendido de um ponto de vista estritamente biológico, sendo este um fenômeno social, tendo "o seu núcleo nas teorias e ideologias e na sua divulgação, que discriminam grupos e pessoas, a elas atribuindo as características de uma 'raça' inferior" (LAFER, 2005, p. 58-59).

Lafer utilizou, ainda, o pensamento de Norberto Bobbio a respeito da discriminação, uma “diferenciação injusta e ilegítima", uma vez que vai contra o princípio fundamental da justiça, o qual reza que os iguais devem ser tratados como tal. Ainda, coloca o doutrinador italiano que o conceito de raça, apesar de não possuir fundamento científico, é bastante presente entre os preconceituosos, que fazem o juízo de existirem raças superiores e inferiores (BOBBIO, 2002, p. 107-110).

Existente cientificamente ou não, o que importa, à luz do direito, é que o pensamento de diferenças entre raças existe, sempre existiu e ainda perdura no imaginário preconceituoso e discriminatório em âmbito mundial, em especial em épocas de crise econômica, onde facilmente se encontra "no outro" a culpa do seu infortúnio. Esta visão do racismo é bem colocada por Eliane Azevêdo:

Mesmo que a crença geral nos fundamentos biológicos para o racismo tenha experimentado algum esvaziamento, novas formas de concepção do 'outro' estão surgindo. O 'outro' é aquele que é estranho, diferente não apenas na aparência, mas também nos valores, crenças, estilo de vida, posição social, etc. Assim, a prática do racismo tornou-se, na sociedade moderna, não apenas mais abrangente como também mais diversificada em suas formas de negar a dignidade, a igualdade e o respeito à pessoa humana (1990, p. 27)

Assim, diante do posicionamento do parecerista Celso Lafer e dos demais autores citados, fica claro o posicionamento jurídico e doutrinário majoritário no sentido de que o preconceito deve ser combatido não pelo significado real do alvo da discriminação, mas sim por aquele imaginado pelos discriminadores. E nesse sentido, a "raça imaginária" estava presente nas obras publicadas por Ellwanger. Sérgio Oliveira, na obra "Hitler: culpado ou inocente" afirma que:

Uma propaganda maciça inculca nas pessoas a impressão de que os judeus são uma "raça perseguida", incapaz de realizar qualquer maldade. E essa propaganda está entorpecendo a capacidade de raciocínio das pessoas, criando uma opinião pública favorável a escusos desígnios, principalmente porque mascara uma ideologia milenar voltada - esta sim! - para a supremacia racial judaica, para a conquista e escravização de todos os outros povos (OLIVEIRA, 1990, p. 15).

Da mesma maneira, esta constatação preconceituosa de raça pode ser constatada no livro "O judeu internacional" de Henry Ford:

Possuindo, como nenhuma outra raça, aversão para todo o trabalho material e produtivo, sabe equilibrar este defeito por uma predisposição característica para o intercâmbio. O não-judeu manifesta sua atividade no terreno industrial ou técnico, enquanto o jovem judeu prefere começar sua carreira como criado, vendedor ambulante ou empregado no comércio, pela relação que tais profissões guardam com o aspecto mercantil $(1989$, p. 12).

Desta forma, tanto pelas obras próprias quanto por aquelas publicadas pela editora Revisão, de propriedade de Ellwanger, reforçam a crença do paciente do habeas corpus de que os judeus constituiriam uma raça à parte, diferente das demais, possuindo características próprias e se encaixando no conceito do "outro", que representaria um perigo para a sociedade e deveria ser combatido. 
Retornando à decisão dos membros do STF quanto ao caso, o primeiro a prolatar seu voto foi o Ministro Moreira Alves, relator do processo, o qual entendeu que, do ponto de vista científico, os judeus não constituem uma raça e, portanto, não existiria crime de racismo por parte de Siegfried Ellwanger, entendendo por deferir o pedido de habeas corpus (BRASIL, 2003, p. 221-228). Após este voto e ponderando a respeito da possibilidade de enquadramento do preconceito contra judeus como racismo, o Ministro Maurício Corrêa pediu vistas do processo.

O voto do Ministro Maurício Corrêa, entregue após sua vista ao processo, ocupa 38 páginas (BRASIL, 2003, p. 239-268) e possui um conteúdo muito mais abrangente do que o colocado pelo relator do processo, sendo que, após versar sobre o real fulcro da discriminação cometida por Siegfried Ellwanger, concluiu que:

A divisão dos seres humanos em raças decorre de um processo político-social originado da intolerância dos homens. Disso resultou o preconceito racial. Não existindo base científica para a divisão do homem em raças, torna-se ainda mais odiosa qualquer ação discriminatória da espécie. (BRASIL, 2003, p. 235)

Assim, a contrário do relator, indeferiu o habeas corpus para Ellwanger. Após o voto de Maurício Corrêa, o relator Ministro Moreira Alves pediu novamente a palavra. Saudando o entendimento de seu colega de Tribunal, reiterou os motivos de seu voto, reafirmando o seu posicionamento pela concessão do habeas corpus. Afirmou, inclusive, que a imprescritibilidade de um crime naquele caso consistiria em uma "aberração jurídica”. (BRASIL, 2003, p. 269-286)

Terminada a confirmação de voto do Ministro Moreira Alves, o Ministro Celso de Mello antecipou seu voto, ressaltando que a questão principal a ser discutida era se a prática de antissemitismo se encaixaria no crime de racismo. Fundamentando amplamente seu voto nos institutos de Direito Internacional, em especial a proteção à dignidade da pessoa humana de qualquer origem, o Ministro acompanhou o entendimento divergente do Ministro Maurício Corrêa, e também votou contrariamente ao habeas corpus, entendendo que "aquele que ofende a dignidade pessoal de qualquer ser humano, especialmente quando movido por razões de fundo racista, também atinge - e atinge profundamente - a dignidade de todos e de cada um de nós". (BRASIL, 2003, p. 287-310)

Passou-se, então, ao voto do Ministro Gilmar Mendes que, da mesma forma que o Ministro Celso de Mello, acreditou que a amplitude do crime de racismo era a questão mais grave a ser solucionada. O Ministro expôs que, indiferentemente do critério antropológico ou biológico, é impossível negar o caráter racista do antissemitismo, que possui um matiz histórico. Ainda, discorreu sobre um eventual choque entre direitos fundamentais: de um lado o direito de expressão e de outro a dignidade humana, utilizando-se para a solução do conflito do princípio da proporcionalidade. Concluiu que ao aplicar a proporcionalidade no caso concreto em análise, deveria preponderar a dignidade humana, a qual foi respeitada pela decisão atacada pelo habeas corpus. Diante disto, também votou pelo indeferimento do remédio constitucional. (BRASIL, 2003, p. 312-346)

Após o pedido de vista do processo por dois Ministros, o Ministro Carlos Velloso antecipou seu voto, ressaltando a evolução histórica dos direitos humanos e registrando a importância do parecer de Celso Lafer a respeito do caso. Entendeu que a liberdade de expressão em momento algum pode se sobrepor à dignidade da pessoa humana, acompanhando, por fim, o voto do Ministro Moreira Alves, o primeiro a discordar do entendimento do Relator. (BRASIL, 2003, p. 351-365)

O Ministro Nelson Jobim, neste momento, também pediu para antecipar seu voto e, de forma sucinta, expôs oralmente seus motivos para indeferir o habeas corpus, sendo que, posteriormente, juntou também o voto por escrito, compilando entendimentos que já haviam sido expostos anteriormente. (BRASIL, 2003, p. 366-424) 
A Ministra Ellen Gracie, da mesma forma, solicitou antecipar seu voto diante dos pedidos de vista ao processo. A Ministra acompanhou o entendimento de seus colegas no sentido de que o conceito de "raça" não poderia ser visto de um ponto de vista biológico, eis que esta distinção, entre seres humanos, é inexistente. Por este motivo, as manifestações racistas não partiriam de um conceito racional/científico e, assim, o preconceito existente nas declarações antissemitas das publicações de Ellwanger enquadrar-se-iam, perfeitamente, no crime de racismo. Indeferiu, também, o habeas corpus. (BRASIL, 2003, p. 425-431)

Por sua vez, o Ministro Cezar Peluso, dizendo não ter mais dúvidas quanto ao caso frente às exposições realizadas pelos seus colegas, também antecipou seu voto e, de forma sucinta, defendeu o entendimento de que restringir o conceito de "raça" à noção científica seria esvaziar o conteúdo da Constituição e não seguir o seu real intuito. Portanto, também denegou o habeas corpus (BRASIL, 2003, p. 425-436). Após o voto do Ministro Cezar Peluso, houve um debate iniciado pelo Ministro Sepúlveda Pertence acerca de uma possível concessão de ofício do habeas corpus frente à uma análise da data em que teriam sido publicadas as obras, se antes ou depois da Constituição de 1988 e das Leis que regularam o crime de racismo. Frente ao fato de que não é possível ao Supremo Tribunal Federal analisar provas, não mais se cogitou neste momento a respeito desta possibilidade. (BRASIL, 2003, p. 425-454)

Terminados os debates, foi dado o voto pelo Ministro Carlos Ayres Britto. O jurista colocou uma breve exposição em que resumiu o entendimento dos demais Ministros que já haviam prolatado seus votos e após passou a introduzir, novamente, o questionamento que tinha sido alvo dos debates anteriores: o crime teria sido realizado antes de vigorarem as Leis que o regulamentaram? Argumentou o Ministro que a mera reedição e venda dos livros posteriormente à Lei não caracterizaria o crime, uma vez que a liberdade empresarial e a livre iniciativa são fundamentos da Constituição brasileira. Por este fundamento, decidiu por conceder de ofício o habeas corpus a Ellwanger. (BRASIL, 2003, p. 456-475) Porém, o Ministro Carlos Ayres Britto, não cessou seu voto neste instante, passando a versar também sobre o mérito do habeas corpus em questão. Colocou, então, que indubitavelmente o racismo se trata de crime imprescritível e inafiançável, e versou longamente a respeito de uma interpretação dos termos "racismo", “preconceito" e "prática". (BRASIL, 2003, p. 475-509)

Chama muito a atenção a parte final do voto do Ministro Ayres Britto, em que ele passa a expor sua visão a respeito das obras escritas e publicadas por Ellwanger. No seu entendimento, Ellwanger possuía um intuito científico e histórico ao escrever suas obras, inclusive elogiou a quantidade de fontes utilizadas por ele ao escrever seus livros. Da mesma forma, indicou que o autor deixava espaço para o senso crítico do leitor, não incitando ódio. Apesar de dizer que as obras não lhe agradaram, o Ministro entendeu que não se podia "negar a ele, paciente, o que é próprio dos estudiosos: a análise de fatos, ações, eventos, personalidades". Segundo o Ministro, portanto, Ellwanger seria meramente um estudioso tendencioso, nada mais, já que, nas palavras de Ayres Britto: "não é crime tecer uma ideologia". (BRASIL, 2003, p. 509-520) Mais surpreendente é o seu argumento no sentido de que as obras não poderiam ser consideradas racistas por não considerarem os judeus inferiores, mas sim acusarem os judeus de um complexo de inferioridade; portanto, não haveria preconceito, já que, segundo o autor, preconceituosos seriam os sionistas. Quanto aos demais livros publicados por Ellwanger, diz o Ministro que ele apenas folheou dois deles: "Os conquistadores do mundo" e "Hitler: Culpado ou inocente", dizendo que "são bem escritos e seguem a mesma toada do livro de autoria do escritor sub judice: dar uma outra versão dos fatos ensejadores do Segundo Grande Conflito Armado do século XX." Por último, coloca que as obras editadas pelo paciente também estão à venda em outros locais do mundo, disponíveis para todos e, assim, não haveria motivos para se ter apenas seus atos como delituosos. Deferiu, assim, o habeas corpus (BRASIL, 2003, p. 520-536).

Terminado o voto do Ministro Carlos Ayres Britto, foi dada vista do processo ao Ministro Marco Aurélio que, por fim, se pronunciou a respeito do caso. Inicialmente, fez um relato sobre os 
demais votos proferidos para então versar a respeito da liberdade de expressão e sua importância em um Estado Democrático de Direito, bem como sobre a necessidade de haver uma certa limitação a este direito. Enfatizou, então, que ao seu ver a questão principal que estava em análise seria se Ellwanger havia instigado ou incitado a prática de racismo. O Ministro, de pronto, respondeu à própria questão: “A resposta, para mim, é desenganadamente negativa." (BRASIL, 2003, p. 532562) Seguiu o Ministro a mesma linha de Ayres Britto, dizendo que não havia nas obras qualquer intenção de induzir preconceito. Para ele "o fato de alguém escrever um livro e outros concordarem com as idéias ali expostas não quer dizer que isso irá causar uma revolução nacional. Mesmo porque, infelizmente, o brasileiro médio não tem sequer o hábito de ler". O voto do Ministro beira à contradição, já que, na sequência, ele reconhece que o autor deixa transparecer em suas obras uma ideia preconceituosa acerca dos judeus, mas não se poderia proibir a divulgação deste pensamento em face da liberdade de expressão, protegida constitucionalmente. (BRASIL, 2003, p. 562-564) Ainda, defendeu o Ministro a tese de que um livro só teria o poder de influenciar uma sociedade caso ela tenha pré-disposição ao preconceito, o que não acontece no Brasil, onde para ele "as mais diferentes formas de divulgação da cultura judaica sempre gozaram de amplo apoio e interesse popular". (BRASIL, 2003, p. 564-570) Pode-se aqui dizer, data maxima venia, que o Ministro se olvidou de todos os registros históricos de antissemitismo existentes na história brasileira, como trazido nos primeiros tópicos deste artigo.

Por fim, utilizou-se o Ministro Marco Aurélio do direito comparado, analisando decisões de Cortes de outros países, bem como fez um resumo do racismo nas Constituições brasileiras para, por fim, trazer o que diz a este respeito a Constituição Federal de 1988. Acompanhando o entendimento do relator, entendeu o Ministro que a imprescritibilidade prevista para o crime de racismo constitui verdadeira "aberração jurídica". Assim, seguiu os entendimentos dos Ministros Moreira Alves e Carlos Britto, deferindo o habeas corpus. (BRASIL, 2003, p. 570-599)

Foi a vez, então, do único que ainda não havia se pronunciado a respeito do caso concreto proferir o seu voto, o Ministro Sepúlveda Pertence. Seguiu a linha exposta pelo jurista italiano Norberto Bobbio, para o qual o "racismo" fere qualquer conjunto humano diverso daquele a que pertence o preconceituoso, restando claro o entendimento de que o antissemitismo se configura em racismo. (BRASIL, 2003, p. 674-678) O Ministro, ao proferir seu voto, revelou se penitenciar pela Corte ter ventilado a possibilidade de um habeas corpus de ofício, com fundamento nos votos dos Ministros Marco Aurélio e Carlos Britto, eis que para ele tratava-se de uma questão impertinente. Após esta afirmação iniciou-se, durante o voto, uma discussão entre os Ministros Sepúlveda Pertence, Marco Aurélio e Carlos Ayres Britto, estando nítido nestes dois últimos o ressentimento pelo posicionamento de Sepúlveda Pertence. Após passado este breve desentendimento, Sepúlveda Pertence seguiu com seu voto, afirmando que, ao contrário da análise realizada por Carlos Ayres Britto, ele via manifestações claramente racistas e preconceituosas nas obras de Ellwanger e, diante disto, indeferiu o habeas corpus. (BRASIL, 2003, p. 678-684)

Deste modo, vencidos os Ministros Moreira Alves, Marco Aurélio e Carlos Ayres Britto, foi indeferido o habeas corpus a Siegfried Ellwanger, por maioria de votos. O Supremo Tribunal Federal, em uma decisão histórica e que traz repercussões até hoje, calcou entendimento de que o antissemitismo se configura como crime de racismo, imprescritível e inafiançável.

\section{CONCLUSÃO}

O antissemitismo se trata de um fenômeno histórico muito debatido na história e, apesar das inúmeras teorias existentes, causa estranheza e constrangimento perceber como o preconceito contra um grupo de pessoas possa ter perdurado tantos séculos, em âmbito mundial, tendo atingido seu monstruoso ápice com o regime nazista, há mais de setenta anos, no chamado holocausto. 
Infelizmente, o preconceito contra os judeus existe praticamente em todas as regiões do planeta, sendo que o Brasil não escapa desta nódoa, apesar do senso comum de que neste país não existe preconceito (afirmação realizada, inclusive, pelo Ministro Marco Aurélio em seu voto).

$\mathrm{O}$ caso Ellwanger, analisado neste trabalho, tratou-se de um marco jurídico importantíssimo pois o Supremo Tribunal Federal, órgão máximo da jurisdição constitucional no país, se debruçou a expressar seu entendimento acerca da extensão do termo "racismo", uma vez que o pedido de habeas corpus em nome do gaúcho fundamentou-se na tese de que antissemitismo não se enquadraria no crime de racismo já que, biológica e antropologicamente, existiria apenas a raça humana. A maioria dos Ministros do Supremo Tribunal Federal entendeu que, apesar de não se poder falar de "raça ariana", "raça judia" ou "raça negra", por exemplo, o intuito do dispositivo da Constituição era criminalizar e punir qualquer tipo de preconceito direcionado a um grupo de pessoas devido à sua origem, crenças ou outro aspecto que o diferenciasse dos demais.

As obras editadas e escritas por Ellwanger, como pôde ser visto, contém forte carga de preconceito e discriminação, ressaltando as diferenças existentes entre as pessoas de origem hebraica das demais. Visava colocá-las como participantes de um movimento internacional para subjugar os Estados e seus cidadãos e com isso, incitar, consequentemente, o ódio contra os judeus, o que de forma alguma poderia ser aceito pela jurisdição constitucional brasileira.

O que torna a presente análise de maior valor para desvelar este pano de fundo ainda presente na sociedade brasileira é, certamente, os votos favoráveis ao habeas corpus, dados pelos Ministros Moreira Alves, Carlos Britto e Marco Aurélio. Moreira Alves, em seu voto, utilizou-se de uma interpretação que esvaziaria por completo a norma constitucional que criminaliza o racismo e o torna imprescritível. Para ele, os casos de antissemitismo não se configuram racismo, por entender que não existem raças.

Entretanto, a questão do racismo é bastante clara na bibliografia. Se no sentido biológico não se pode falar de uma divisão humana em raças, fica transparente que no imaginário histórico de preconceitos esta partição existe e, para o Direito, ramo que lida com os conflitos existentes na sociedade, importam muito mais as compreensões existentes nos grupos sociais do que conceitos científicos frios e desconectados da realidade social. O Ministro se posicionou de forma bastante positivista, interpretando uma palavra meramente pelo seu significado, sem buscar compreender o objetivo buscado pela norma (interpretação teleológica), que é o de não permitir a discriminação. Além disso, não ponderou o impacto que tal entendimento poderia ter em uma sociedade plural e desigual como a brasileira.

Os Ministros Carlos Britto e Marco Aurélio, por sua vez, não viram nas obras de Ellwanger um caráter preconceituoso, apesar do que pôde ser visto no decurso do presente artigo a respeito do conteúdo de tais livros. Chegou-se ao absurdo de colocar que as obras pretendiam apenas realizar uma abordagem histórica de fundo científico e, portanto, não se poderia tolher o direito à liberdade de expressão, mesmo frente às informações deturpadas constantes nas obras.

É claro que, mesmo entendendo que qualquer atitude preconceituosa contra um grupo de pessoas configurasse racismo, haveria inevitavelmente um choque entre dois direitos fundamentais: a liberdade de expressão e a dignidade da pessoa humana. Este choque, que só pode ser resolvido analisando-se o caso concreto através do princípio da ponderação, fica patente no caso Ellwanger, porém a solução, após um estudo a respeito do caso, é bastante evidente. Não se pode permitir que a liberdade de expressão assuma tal vulto a ponto de se sobrepor à dignidade de um grupo. Atentar, em um Estado Democrático de Direito, contra a dignidade de uma pessoa ou de um grupo é ir contra toda a coletividade, o que não pode ser aceito em nenhuma hipótese.

Em épocas de extremismos tanto de direita quanto de esquerda, de intolerância e da exacerbação de um discurso de ódio nas relações humanas presenciais e virtuais, a mensagem final consolidada no acórdão oriundo do Supremo Tribunal Federal ainda em 2003 é extremamente positiva. O preconceito não pode ser tolerado, em nenhuma de suas formas, eis que irracional e prejudicial à humanidade como um todo. Porém, é motivo de preocupação ainda naquela época a 
existência de votos de três Ministros que galgaram ao maior posto do judiciário brasileiro, os quais se deram no sentido de que, em determinadas situações, o preconceito minimamente velado pode ser aceito em nome da liberdade de expressão ou de uma interpretação literal e fria de uma norma legal.

As manifestações da maioria dos Ministros do Supremo Tribunal Federal reafirmaram, com extrema pertinência, "que a racialidade não está assentada em determinações biológicas", mas sim em fatores culturais. E isso requer "medidas específicas fundadas na racialidade segregada para romper com os atuais padrões de apartação social". Nesse sentido, "o fim da discriminação deverá ser cimentado pela igualdade econômica".

E para contribuir com este entendimento, abril de 2012 o Plenário do Supremo Tribunal Federal (STF) considerou constitucional a política de cotas étnico-raciais para seleção de estudantes da Universidade de Brasília. Por unanimidade, os ministros julgaram improcedente a Arguição de Descumprimento de Preceito Fundamental (ADPF) 186, ajuizada na Corte pelo Partido Democratas (DEM). Entendeu-se nesta decisão que a política de cotas para o acesso ao ensino superior visa combater a estas racialidades historicamente construídas, ao pregar a igualdade de condições e oportunidades para os jovens negros sendo, portanto, constitucional. (SUPREMO TRIBUNAL FEDERAL, 2020a) Posteriormente, foi editado o Estatuto da Igualdade Racial (Lei 12.228/2010), o qual determinou ser dever do Estado e da sociedade garantir a igualdade de direitos e oportunidades, independentemente da etnia ou da cor da pele, devendo ser combatida a discriminação e as demais formas de intolerância étnica.

Por sua vez, em junho de 2017 o Plenário do Supremo Tribunal Federal julgou a Ação Declaratória de Constitucionalidade n. 41, reconhecendo por unanimidade a validade da Lei $12.990 / 2014$, a qual reserva para negros $20 \%$ das vagas oferecidas em concursos públicos para provimento de cargos efetivos e empregos públicos no âmbito da administração pública federal direta e indireta, no âmbito dos Três Poderes. Para a Ministra Carmen Lúcia, o preconceito contra negros, judeus, idosos ou contra mulheres "é insidioso e existe de forma acobertada, e outras vezes é traduzido em brincadeiras, que nada mais são do que verdadeiras injúrias, que indignam." Ao decidir pela constitucionalidade da Lei 12.990/2014 e demais políticas afirmativas, como a questão das cotas para deficientes, o Supremo Tribunal Federal andou bem, "ao tornar visível o que se passa na sociedade". (SUPREMO TRIBUNAL FEDERAL, 2020b)

O caminho para que o Brasil se torne, de fato, uma sociedade livre de preconceitos é árduo, cotidiano e interminável. Não é possível permitir que terríveis máculas históricas, como a escravidão e o holocausto, sejam apagadas e deixem de existir na memória de todos. A lembrança destes tristes momentos é o que permite que se veja o "outro" como igual, afinal, como decidido pelo Supremo Tribunal Federal, todos indivíduos, independente das suas peculiaridades e diversidades, fazem parte da mesma raça humana, sem distinções.

\section{REFERÊNCIAS}

ACADEMIA BRASILEIRA DE LETRAS. Gustavo Barroso: Biografia. Disponível em: <http://www.academia.org.br/academicos/gustavo-barroso/biografia>. Acesso em 14 dez. 2019.

ARENDT, Hannah. Origens do totalitarismo. Tradução Roberto Raposo. 6 ed. São Paulo: Companhia das Letras, 2006.

AZEVÊDO, Eliane. Raça: conceito e preconceito. 2. ed. São Paulo: Ática S.A., 1990.

BARROSO, Gustavo. História Secreta do Brasil. Vol. I. Porto Alegre: Editora Revisão Ltda, 1990. 
BAUMAN, Zygmunt. Modernidade e Holocausto. Rio de Janeiro: Jorge Zahar, 1998.

BEN-DROR, Graciela. As elites católicas do Brasil e suas atitudes em relação aos judeus. In: Carneiro, Maria Luiza Tucci (org.). O anti-semitismo nas Américas. São Paulo: Editora da Universidade de São Paulo: Fapesp, 2007.

BOBBIO, Norberto. Elogio da serenidade e outros escritos morais. Tradução Marco Aurélio Nogueira. São Paulo: UNESP, 2002.

BRAGA, Alfredo. Siegfried Ellwanger. Disponível em: <https://foradamidia.blogspot.com/2011/05/siegfried-ellwanger.html>. Acesso em 14 dez. 2019.

BRASIL. Constituição da República Federativa do Brasil. Brasília, 1988. Disponível em: < https://www2.senado.leg.br/bdsf/bitstream/handle/id/518231/CF88_Livro_EC91_2016.pdf>. Acesso em: 15 dez. 2019.

BRASIL. Lei n 7.716, de 05 de janeiro de 1989. Brasília, 1989. Disponível em: <http://www.planalto.gov.br/ccivil_03/leis/L7716compilado.htm>. Acesso em: 15 dez. 2019. 2012.

BRASIL. Código Penal Brasileiro. Brasília, 1940. Disponível em: <https://www2.senado.leg.br/bdsf/bitstream/handle/id/529748/codigo_penal_1ed.pdf>. Acesso em: 15 dez. 2019.

BRASIL. Supremo Tribunal Federal. Habeas Corpus 82.424-2/RS. Paciente: Siegfried Ellwanger. Impetrante: Werner Cantalício João Becker. Coator: Superior Tribunal de Justiça. Relator: Ministro Moreira Alves. Brasília, 2003.

CARNEIRO, Maria Luiza Tucci. Preconceito racial: Portugal e Brasil-colônia. 2. ed. São Paulo: Editora Brasiliense, 1988.

CASTAN, S. E. Holocausto: Judeu ou alemão. Porto Alegre: Revisão Editora Ltda, 1987.

CPDOC. Gustavo Barroso. Disponível em:

<http://cpdoc.fgv.br/producao/dossies/AEraVargas1/biografias/gustavo_barroso>. Acesso em 14 dez. 2019.

ESCHAPASSE, Baudouin. Judeus sem saber. Out. 2009. Disponível em:

<http://chapermannmyblog.wordpress.com/2009/09/29/judeus-sem-saber-continuacao/>. Acesso em 14 dez. 2019.

FINZI, Roberto. Anti-semitism: from its european roots to the holocaust. Nova Iorque: Interlink Books, 1999.

FORD, Henry. O judeu internacional. Porto Alegre: Revisão Editora Ltda: 1989.

GRINBERG, Keila. Judeus, judaísmo e cidadania no Brasil Imperial. Disponível em:

<http://www.numemunirio.org/pesquisadores/keilagrinberg/?c=download_biblio\&arq=MzU\%3D $>$ Acesso em 14 dez. 2019. 
LAFER, Celso. A internacionalização dos direitos humanos: Constituição, racismo e relações internacionais. Barueri: Manole, 2005.

LESSER, Jefrey. Semitismo em negociação: O Brasil e a questão judaica (1930-1945). In: Carneiro, Maria Luiza Tucci (org.). O anti-semitismo nas Américas. São Paulo: Editora da Universidade de São Paulo Fapesp, 2007.

MESSADIÉ, Gerald. História geral do anti-semitismo. Tradução Rejane Janowitzer. Rio de Janeiro: Bertrand Brasil, 2003.

OLIVEIRA, Sérgio. Hitler: culpado ou inocente? Porto Alegre, Revisão Editora Ltda: 1990.

SILVA, Leonardo Dantas da. Colonizadores da América. Nov. 2010. Disponível em: <http://www.revistadehistoria.com.br/secao/capa/colonizadores-da-america>. Acesso em: 03 jul. 2012.

SUPREMO TRIBUNAL FEDERAL. Doutora em Filosofia pela USP defende cotas para negros e lembra julgamento em que STF discutiu conceito de raça. Disponível em: http://www.stf.jus.br/portal/cms/verNoticiaDetalhe.asp?idConteudo=121288. Acesso em 28 fev. 2020a.

SUPREMO TRIBUNAL FEDERAL. Plenário declara constitucionalidade da Lei de Cotas no serviço público federal. Disponível em:

http://www.stf.jus.br/portal/cms/verNoticiaDetalhe.asp?idConteudo=346140. Acesso em 28 fev. $2020 b$.

WOLFF, Egon; WOLFF, Frieda. Judeus no Brasil Imperial. São Paulo: USP, 1975. 